\title{
A new arthropod from the lower Cambrian Sirius Passet Fossil-Lagerstätte of North Greenland
}

\author{
JoHN S. PEEL \& MARTIN STEIN
}

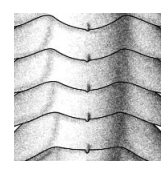

\begin{abstract}
Aaveqaspis inesoni gen. et sp. nov., is described from the lower Cambrian Sirius Passet Fossil-Lagerstätte of Peary Land, North Greenland. It has a semicircular head shield and a thorax with 5 tergites. The tail shield carries 2 pairs of spines, the most anterior of which is enormous and dominates the trunk. A. inesoni lacks any preserved trace of eyes, as is also the case with several other Sirius Passet arthropods, suggesting that the fossils accumulated in deeper water than the contemporaneous Chengjiang Fossil-Lagerstätte of China or the middle Cambrian Burgess Shale assemblages of British Columbia. • Key words: Cambrian, arthropod, Sirius Passet, Lagerstätte, Greenland.
\end{abstract}

PeEL, J.S. \& Stein, M. 2009. A new arthropod from the lower Cambrian Sirius Passet Fossil-Lagerstätte of North Greenland. Bulletin of Geosciences 84(4), 625-630 (3 figures). Czech Geological Survey, Prague. ISSN 1214-1119. Manuscript received July 30, 2009; accepted in revised form September 22, 2009; published online October 9, 2009; issued December 31, 2009.

John S. Peel, Department of Earth Sciences (Palaeobiology), Uppsala University, Villavägen 16, SE-75 236 Uppsala, Sweden; John.Peel@pal.uu.se • Martin Stein, Museum of Evolution, Uppsala University, Norbyvägen 16, SE-752 36 Uppsala, Sweden; Martin.Stein@evolmuseum.uu.se

Black laminated mudstones and siltstones juxtaposed against the prominent buried escarpment of an eroded carbonate platform in Peary Land, North Greenland (Fig. 1), yield the rich fossil assemblage comprising the Sirius Passet Fossil-Lagerstätte (Conway Morris et al. 1987, Conway Morris 1998, Babcock \& Peel 2007). The geological setting is similar to that of the middle Cambrian Burgess Shale of British Columbia (see summary by Hagadorn 2002). The North Greenland fossils, however, are of early Cambrian age (Cambrian Series 2, Stage 3), and thus some 10 my older than the Burgess Shale. As such, the Sirius Passet biota is the oldest major Fossil-Lagerstätte from the Cambrian of Laurentia and equivalent in age to the Chengjiang Fossil-Lagerstätte of southern China (Chen 2004, Hou et al. 2004). The Sirius Passet Fossil-Lagerstätte occurs within the Buen Formation which overlies the carbonate platform dolomites of the Portfjeld Formation throughout central North Greenland (Fig. 1B; Peel \& Sønderholm 1991, Ineson \& Peel 1997).

The Sirius Passet biota is dominated by arthropods with unmineralized cuticle, some of which have been described in publications by Budd (1993, 1995, 1997, 1998, 1999a, b), Budd \& Peel (1998), Williams et al. (1996), Taylor (2002), Stein (in press), Stein et al. (in press) and Lagebro et al. (2009). Other finds include sponges (Rigby 1986), the earliest annelids (Conway Morris \& Peel 2008), palaeoscolecidans and articulated halkieriids (Conway Morris \& Peel 1990, 1995; Vinther \& Nielsen 2005). The most conspicuous taxon with biomineralized hard parts is the trilobite Buenellus Blaker, 1988 which, although restricted to this locality (Blaker \& Peel 1997), indicates the Nevadella Zone of the early Cambrian of North American usage, equivalent to Series 2 (Stage 3) of the developing chronostratigraphic scale for the Cambrian (Babcock et al. 2005, Zhu et al. 2006).

In this paper we describe a new arthropod species, Aaveqaspis inesoni gen. et sp. nov., from the Sirius Passet Fossil-Lagerstätte that is characterised by a pair of exceptionally large spines on the tail shield, comprising more than $40 \%$ of the total body length. While not preserving limbs or traces of the digestive tract known from some members of the biota, $A$. inesoni is similar to several other co-occurring arthropods in lacking evidence of eyes. Ivantsov et al. (2005) speculated that the absence of the frondose algae which are conspicuous in the Burgess Shale and Chengjiang Fossil-Lagerstätten suggested that the Sirius Passet biota lived in deeper water. The lack of preserved evidence for visual organs in the majority of benthic elements of the arthropod fauna is in line with that hypothesis, although eyes were developed in the trilobite Buenellus higginsi Blaker, 1988 (Blaker \& Peel 1997, Babcock \& Peel 2007). A putative eye is reported from the presumedly pelagic Isoxys volucris Williams, Siveter \& Peel, 1996 (Stein et al. in press).

The tergites in all 3 known specimens of Aaveqaspis inesoni, as preserved, are imbricated such that low angle light in the illustrations (Figs 2A, 3A, B) strikes the raised 


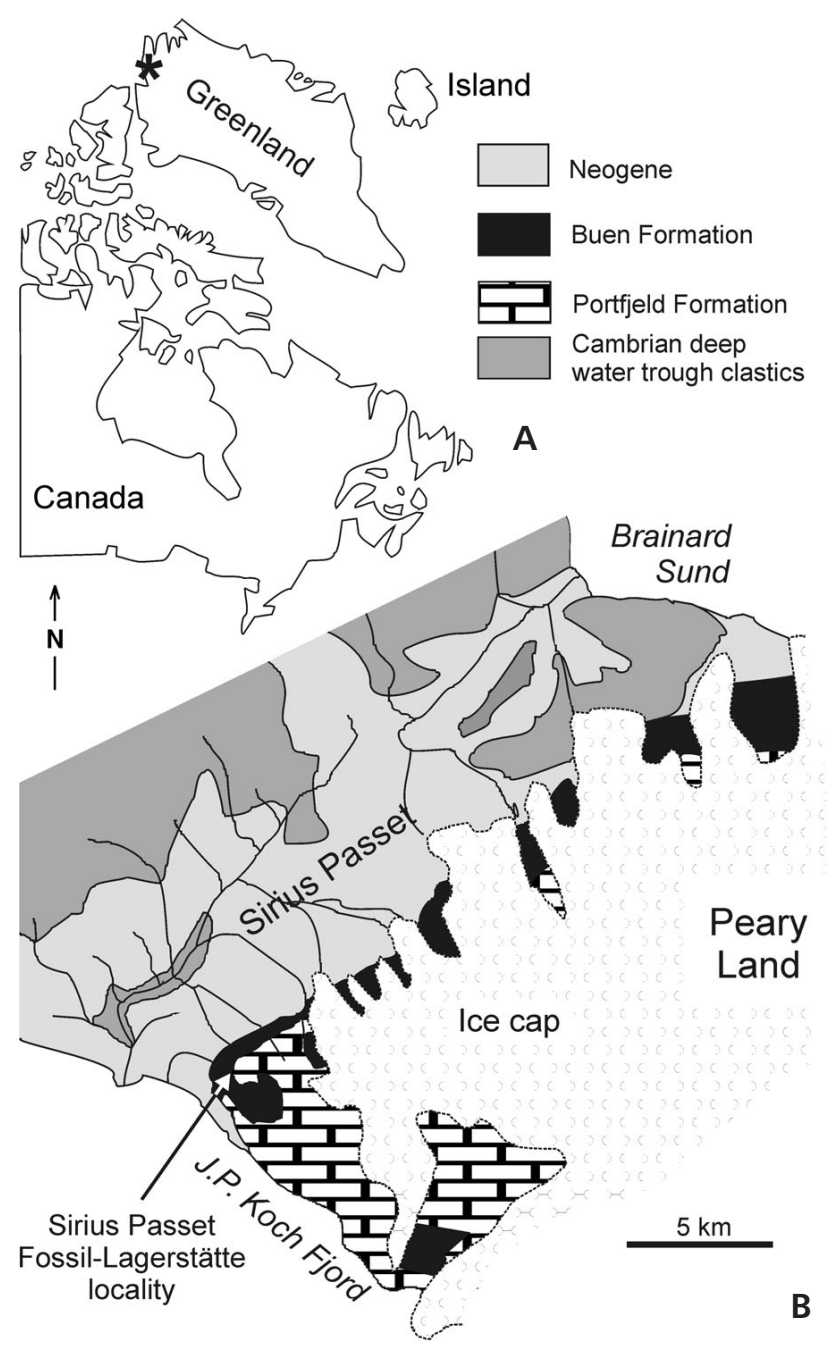

Figure 1. Location of the Sirius Passet Fossil-Lagerstätte in North Greenland (A) with geological map of the area around the locality (B).

anterior margin of each following tergite as it overlies the preceding one. In life, in dorsal view, the anterior margin of each tergite is overlain by the posterior margin of the preceding tergite. Thus, all three specimens are interpreted as external moulds of the tergites, although similar imbrication would result in a view of the interior of the exoskeleton.

The paratypes are more affected by lateral compression than the holotype. This compaction results in a more parabolic outline of the head shield and also affects the splay of the large pygidial spines which accounts for variation of the maximum width in the specimens between $10.5 \mathrm{~mm}$ and $14.8 \mathrm{~mm}$. In both paratypes (Fig. 3), lateral compaction has resulted in shortening of one side with the axis appearing as a broad fold; the axial nodes are impressed in the apex of this fold. This skewing of the tergites indicates considerable convexity in life. The large splay between the free tergopleural extremities and the large tergal overlap in the axis were likely adaptions for dorsoventral flexure necessitated by the large convexity.
The surface of paratype C (Fig. 3B) is crossed by a series of narrow burrows, about $0.1 \mathrm{~mm}$ wide. Preservation of fine burrows within the area of individual fossils is a common phenomenon in the Sirius Passet FossilLagerstätte and has been noticed by several authors (e.g., Babcock \& Peel 2007). Frequently, the burrows can be traced for a short distance beyond the margin of the fossil before merging into the surrounding sediment, indicating that their three dimensional preservation is probably a diagenetic effect representing early mineralization within the area of sediment affected by the decaying carcass. The burrows cross the compactional fold without deflection, which may indicate that they were formed after compaction of the carcass.

The similarity in size between the 3 specimens is noteworthy; the occurrence of several specimens of Kleptothule rasmusseni Budd, 1995 on the same slabs as 2 of the specimens of A. inesoni may suggest derivation from the same stratum, although all 3 specimens were collected from talus.

Material. - Figured specimens are deposited in the type collection of the Geological Museum (Natural History Museum of Denmark), Copenhagen, Denmark (MGUH prefix).

\section{Systematic palaeontology}

Arthropoda von Siebold \& Stannius, 1845

\section{Genus Aaveqaspis gen. nov.}

Type species. - Aaveqaspis inesoni gen. et sp. nov., early Cambrian (Nevadella Zone of Laurentian usage); Cambrian Series 2, Stage 3, Sirius Passet Fossil-Lagerstätte, Peary Land, North Greenland.

Etymology. - From Aaveq (Greenlandic, walrus), reflecting the fancied resemblance of the tail spines to the prominent tusks of the arctic mammal, and aspis (Greek, shield).

Diagnosis. - Body narrowly oval, with a weakly defined axis; dominated by a pair of broad, elongate spines, which form most of the tail shield. Head shield semicircular without dorsal eyes, with stubby genal spines; thorax parallel-sided, with 5 free overlapping tergites, strongly curved in dorsal view and drawn out laterally into robust spines; tail with two pairs of broad spines, of which the first pair is macropleural, extending far to the posterior of the inner pair.

Description. - As for type species, below.

Discussion. - As for type species, below. 

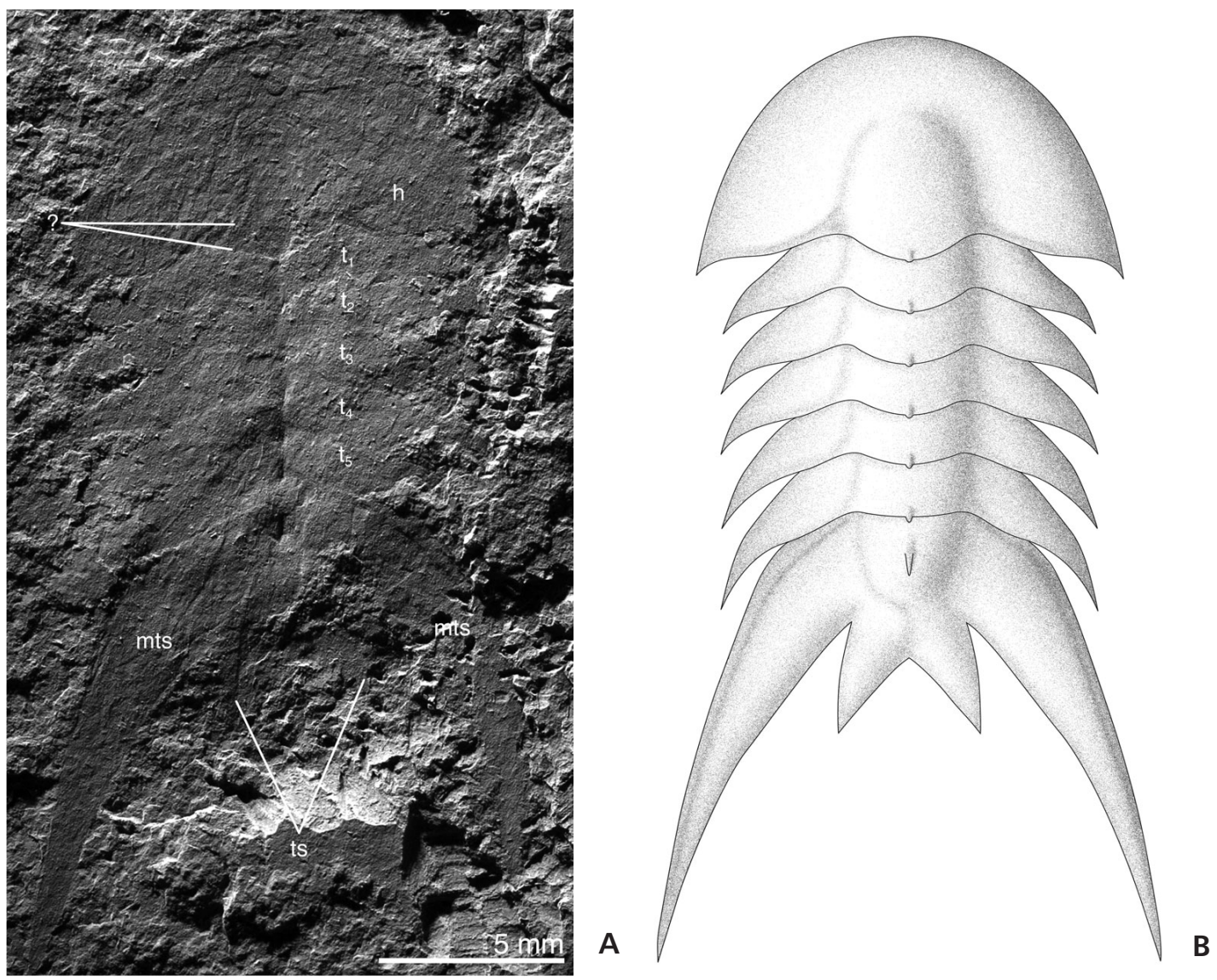

Figure 2. Aaveqaspis inesoni gen. et sp. nov., Sirius Passet Fossil-Lagerstätte, Buen Formation (early Cambrian), Sirius Passet, Peary Land, North Greenland, holotype, MUGH 29,130. $\bullet$ A - view of external mould with lighting from upper left. $\bullet B-$ interpretive drawing; $h-$ head shield, $\mathrm{t}_{1}-\mathrm{t}_{5}-$ tergites, $\mathrm{mts}-$ macropleural tail spine, ts - tail spine.

\section{Aaveqaspis inesoni sp. nov.}

Figures 2, 3

Holotype. - MGUH 29,130 from the Buen Formation, Sirius Passet Fossil-Lagerstätte, Peary Land, North Greenland, (latitude $82^{\circ} 47^{\prime} 6^{\prime \prime} \mathrm{N}$, longitude $42^{\circ} 13^{\prime} 7^{\prime \prime} \mathrm{W}$ ), on the south side of the broad valley known as Sirius Passet at its junction with J.P. Koch Fjord (Fig. 1).

Paratypes. - MGUH 29,131 and 29,132 from the same locality and horizon as the holotype.

Etymology. - For Jon R. Ineson, in appreciation of his studies of the Cambrian of North Greenland.

Diagnosis. - As for genus, above.

Description - The total length is about $26 \mathrm{~mm}$. The head shield is semicircular, weakly trilobate; the axis is only marked by a slight change in relief and an extension of the posterior margin, an axial furrow is not developed. Axis roughly cylindrical, about one fifth of the total width of the head shield; it tapers slightly towards the anterior, and ex- tends about two thirds of the distance towards the anterior margin. The posterolateral corners of the head shield form acute but short genal spines. The posterior extension of the axial margin of the head shield overlaps the axis of the first tergite; it carries a median node.

The trunk consists of 5 free tergites, each about $1.6 \mathrm{~mm}$ long (sag.) and a tail shield. The tergites have a weakly defined axis, occupying about one third of the tergal width, projecting posteriorly in a process overhanging the posteriorly adjacent tergite by about a quarter of the tergal length. As in the head shield, the process carries an anteroposteriorly elongate median node; the size of the nodes increases in the more posterior tergites. No axial furrow is developed. The tergopleurae are extended into acute pleural spines with gently arched anterior margins. The posterior margins are shallowly concave, producing a considerable splay between successive spines.

The tail shield is dominated by a pair of large segmental marginal spines, reminiscent of macropleural spines in the thorax and pygidial spines of certain trilobites. The axis of the tail shield is weakly defined; it carries one node which is larger and more sharply defined than the nodes on the tergites. The anterior border of the tail shield is convex and 

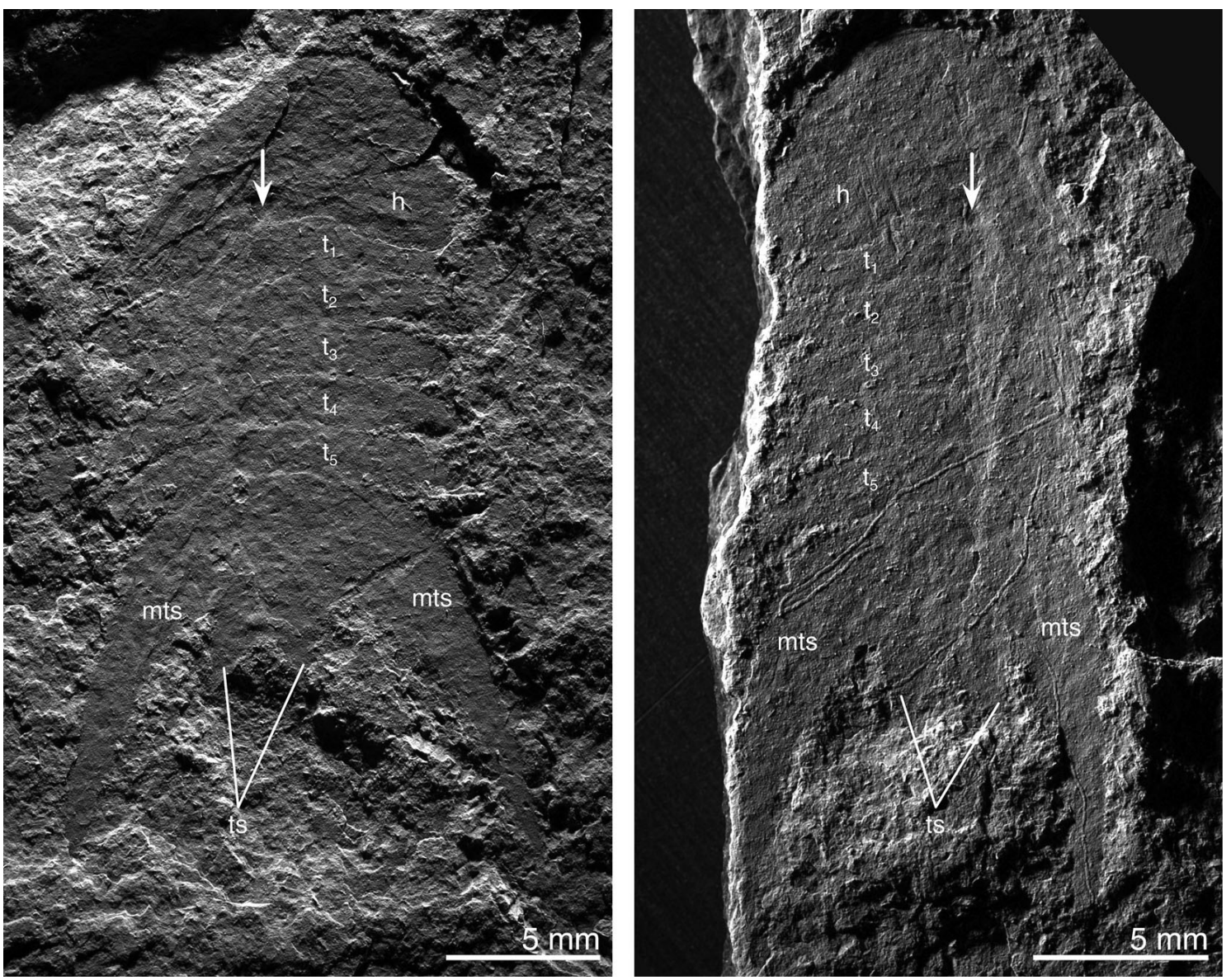

Figure 3. Aaveqaspis inesoni gen. et sp. nov., Sirius Passet Fossil-Lagerstätte, Buen Formation (early Cambrian), Sirius Passet, Peary Land, North Greenland. A- paratype, MGUH 29,131, view of external mould with slight deformation of left side of specimen due to compaction, lighting from anterior. • B - paratype, MGUH 29,132, view of external mould with slight deformation of left side of specimen due to compaction, lighting from upper left. Note fine burrows differentially preserved within the area of the fossil. Arrows indicate the median axis in the compacted and distorted specimens; for explanation see Fig. 2.

curves laterally into the large spines which extend postero-laterally, constituting half the total body length. An oblique ridge extends from the axis concentric with the anterolateral margin of the large spines to the tips. The posterior margin of the spines is concave and merges into a second pair of short, broad, triangular spines located one on each side of a median embayment; a terminal spine is not present. The ventral morphology is unknown.

\section{Discussion}

Aaveqaspis inesoni, the type species, from the Sirius Passet Fossil-Lagerstätte is the only species currently assigned to the genus. The huge spines arising from the anterior of the tail shield serve to distinguish $A$. inesoni from other described Cambrian arthropod species with unmineralized cuticle ( $c f$. Størmer 1959, Simonetta \& Delle Cave 1991, Chlupáč 1995, Hou \& Bergström 1997), although spines of similar size are not infrequently developed in various ceratopygid, cheirurid, crepicephalid damesellid and zacanthoidid trilobites (Harrington et al. 1959). Interpretation of the large marginal spines of the tail shield of $A$. inesoni as segmental is supported by the presence of an axial node, analogous to the nodes on the free tergites of the trunk. There is no indication of a functional joint between the segment with the macropleural spines and the remainder of the tail shield. Buenaspis forteyi Budd, 1999 from the Sirius Passet fauna is most similar in general body form to A. inesoni (Budd 1999a), although the tail shield lacks marginal spines. Buenaspis forteyi is isopygous, with 6 thoracic tergites instead of the 5 of A. inesoni.

Among species from the Chengjiang Fossil-Lagerstätte, Acanthomeridion serratum Hou, Chen \& Lu, 1989 is similar in displaying large spines in the posterior region of the trunk and a deep median embayment of the most posterior sclerite, although the posterolateral extremities of that sclerite are rounded rather than pointed like the smaller triangular spines of $A$. inesoni. Importantly, the large spines in Acanthomeridion serratum arise from a free tergite, and there is another tergite between this spine bearing tergite 
and the terminal tergites, whereas all spines in Aaveqaspis inesoni are part of one ankylosed plate. A terminal spine is present in Acanthomeridion serratum but not in A. inesoni. Also, Acanthomeridion serratum has a more parabolic head shield, with dorsal sutures, a considerably wider thoracic axis and tightly spaced tergopleural spines.

Aaveqaspis inesoni shows some similarity to Sinoburius lunaris Hou, Ramsköld \& Bergström, 1991 from the Chengjiang Fossil-Lagerstätte. Both have a semicircular head shield with a weakly defined axis and an obliquely sinuous posterior border. The genal spines of $S$. lunaris are relatively longer, but their form is similar. The most distinguishing feature in the head shield of S. lunaris is the presence of bulges to accommodate lateral eyes (Edgecombe \& Ramsköld 1999) but there is no evidence of eyes in A. inesoni. The thoracic tergites in both taxa show similar, distinct, imbrication and similarly-shaped pleural extremities ( $c f$. Hou \& Bergström 1997, fig. 77C, D), but the first trunk tergite in A. inesoni has almost the same width as the following tergites. In contrast, the first trunk tergite in S. lunaris is considerably narrower than the following tergites, a feature which has been given some weight in the discussion of affinities of S. lunaris (Edgecombe \& Ramsköld 1999). Furthermore, there is no evidence of a ridge across the pleural field to the tip in A. inesoni. The pygidia of the two taxa are similar in having segmental marginal spines, but there is no evidence of a broad based median spine in A. inesoni. It is unclear if the nodes on the posterior tergites of $A$. inesoni were the base of a median axial spine (cf. Edgecombe \& Ramsköld 1999, character 23), but their occurrence on multiple tergites renders such an interpretation unlikely. The status of the marginal spines on the tail of $S$. lunaris is unclear. Two pairs of tail spines of roughly equal size are reported, which is consistent with a specimen figured by Luo et al. (1997, pl. II, fig. 4), but a specimen figured by Edgecombe \& Ramsköld (1999, fig. 1.2) carries a pair of considerably larger lateral spines that are more similar to, albeit still smaller than, those in A. inesoni.

Sinoburius lunaris is commonly recognized as sister taxon to the Xandarellida Chen, Ramsköld, Edgecombe \& Zhou in Chen et al. 1996 (Hou \& Bergström 1997, Edgecombe \& Ramsköld 1999, Cotton \& Braddy 2004), together constituting the Petalopleura Hou \& Bergström, 1997. Synapomorphies for Petalopleura proposed by Edgecombe \& Ramsköld (1999) include a head incorporating antennular and four postantennular limb-bearing segments, the presence of eye slits, a head shield covering an anteriorly tapering trunk, or rather accommodating the narrow anterior trunk tergite in an posteromedian embayment (Hou \& Bergström 1997), and an axial spine on the posterior tergite. It may be added here that tergites of Xandarella spectaculum Hou, Ramsköld \& Bergström, 1991 carry a pleural ridge (Hou \& Bergström 1997, figs 68D, E, 69A, B), as described from S. lunaris, although the status of that structure is unclear in Cindarella eucalla Chen,
Ramsköld, Edgecombe \& Zhou in Chen et al. 1996. As no limbs are preserved in $A$. inesoni, the number of limb bearing segments in the head cannot be established. Neither is there evidence of eye slits in A. inesoni. The presence of an axial spine in $A$. inesoni is also unclear. A raised ridge on the tergopleurae is present in the large marginal spines of the tail shield, but can not be traced in the trunk tergites. Given this, it seems tenuous to include A. inesoni in Petalopleura or even to regard it as forming a sister group. The lack of traceable synapomorphies in A. inesoni demonstrates that the similarities are superficial; better preserved material is needed to resolve its affinities.

\section{Acknowledgements}

A logistic framework established by the Geological Survey of Greenland (GGU; now GEUS, Geological Survey of Denmark and Greenland, Copenhagen) and the Danish Polarcenter, Copenhagen, permitted expeditions to visit Sirius Passet in 1989, 1991, 1994 and 2006. Grants to support field work (1989-94) from the Carlsberg Foundation, Copenhagen, and National Geographic Society, Washington D.C., to J.S.P. and Simon Conway Morris (Cambridge, U.K.) are gratefully acknowledged, as is finance from the Danish Natural Science Research Council to GEUS for field work in 2006. We also acknowledge financial support to J.S.P. from the Swedish Research Council (Vetenskapsrådet). M.S. received support from the SYNTHESYS Project (http://www.synthesys.info/) which is financed by European Community Research Infrastructure Action under the FP6 Structuring the European Research Area Programme. Reviews for the journal by Petr Budil and Greg D. Edgecombe are gratefully acknowledged.

\section{References}

BABCOCK, L.E. \& PEEL, J.S. 2007. Palaeobiology, taphonomy, and stratigraphic significance of the trilobite Buenellus from the Sirius Passet Biota, Cambrian of North Greenland. Memoirs of the Association of Australasian Palaeontologists 34, 401-418.

BABCOCK, L.E., PENG, S.C., GEYER, G. \& SHERGOLD, J.H. 2005. Changing perspectives on Cambrian chronostratigraphy and progress toward subdivision of the Cambrian System. Geosciences Journal 9, 101-106. DOI 10.1007/BF02910572

BLAKER, M.R. 1988. A new genus of nevadiid trilobite from the Buen Formation (Early Cambrian) of Peary Land, central North Greenland. Grønlands Geologiske Undersøgelse Rapport 137, 33-41.

BLAKER, M.R. \& PEEL, J.S. 1997. Lower Cambrian trilobites from North Greenland. Meddelelser om Grønland, Geoscience 35, $1-145$.

BUDD, G.E. 1993. A Cambrian gilled lobopod from Greenland. Nature 364, 709-711. DOI 10.1038/364709a0

BUDD, G.E. 1995. Kleptothule rasmusseni gen. et sp. nov.: an ?olenellinid-like trilobite from the Sirius Passet fauna (Buen Formation, Lower Cambrian, North Greenland). Transactions of the Royal Society of Edinburgh, Earth Science 86, 1-12.

BUDD, G.E. 1997. Stem group arthropods from the Lower Cambrian Sirius Passet fauna of North Greenland, 125-138. In FORTEY, 
R.A. \& THOMAs, A.H. (eds) Arthropod Relationships. The Systematics Association Special Volume 55.

BUDD, G.E. 1998. Arthropod body-plan evolution in the Cambrian with an example from anomalocaridid muscle. Lethaia 31, 197-210.

BUDD, G.E. 1999a. A nektaspid arthropod from the early Cambrian Sirius Passet fauna, with a description of retrodeformation, based on functional morphology. Palaeontology 42, 99-122. DOI 10.1111/1475-4983.00064

BUDD, G.E. 1999b. The morphology and phylogenetic significance of Kerygmachela kierkegaardi Budd (Buen Formation, Lower Cambrian, N Greenland). Transactions of the Royal Society of Edinburgh, Earth Science 89, 249-290.

BudD, G.E. \& PEEL, J.S. 1998. A new xenusiid lobopod from the Early Cambrian Sirius Passet fauna of North Greenland. Palaeontology 41, 1201-1213.

CHEN, J. 2004. The Dawn of the animal world. 367 pp. Jiangsu Publishing House of Science and Technology, Nanjing. [in Chinese]

CHEN, J., ZHOU, G., ZHU, M. \& YEH, K. 1996. The Chengjiang Biota. A unique window of the Cambrian Explosion. 222 pp. The National Museum of Natural Science, Taichung, Taiwan. [in Chinese]

CHLUPÁČ, I. 1995. Lower Cambrian arthropods from the Paseky Shale (Barrandian area, Czech Republic). Journal of the Czech Geological Society 40, 9-25.

CONWAY MORRIS, S. 1998. The Crucible of Creation. The Burgess Shale and the Rise of Animals. 242 pp. Oxford University Press, Oxford, New York \& Melbourne.

CONWAY MORRIS, S. \& PEEL, J.S. 1990. Articulated halkieriids from the Lower Cambrian of North Greenland. Nature 345, 802-805. DOI 10.1038/345802a0

CONWAY MORRIS, S. \& PEEL, J.S. 1995. Articulated halkieriids from the Lower Cambrian of of North Greenland and their role in early protostome evolution. Philosophical Transactions of the Royal Society of London B 347, 305-358.

DOI 10.1098/rstb.1995.0029

CONWAY MORRIS, S. \& PEEL, J.S. 2008. The earliest annelids: Lower Cambrian polychaetes from the Sirius Passet Lagerstätte, Peary Land, North Greenland. Acta Palaeontologica Polonica 53, 137-148.

Conway Morris, S., PeEl, J.S., Higgins, A.K., SoPer, N.J. \& DAVIS, N.C. 1987. A Burgess Shale-like fauna from the Lower Cambrian of Greenland. Nature 326, 181-183. DOI 10.1038/326181a0

COTTON, T.J. \& BRADDY, S.J. 2004. The phylogeny of arachnomorph arthropods and the origin of the Chelicerata. Transactions of the Royal Society of Edinburgh: Earth Sciences 94, 169-193.

EDGECOMBE, G.D. \& RAMSKÖLD, L. 1999. Relationships of Cambrian Arachnata and the systematic position of Trilobites. Journal of Paleontology 73, 263-287.

HAGADORN, J.W. 2002. Burgess Shale: Cambrian Explosion in full bloom, 61-89. In BOTTJER, D.J., ETTER, W. HAGADORN, J.W. \& TANG, C.M. (eds) Exceptional fossil preservation. Columbia University Press, New York.

Harrington, H.J., Henningsmoen, G., Howell, B.F., JaAnUSSON, V., LOCHMAN-BAlK, C., MOORE, R.C., POUlSEN, C., RASETTI, F., RICHTER, E., RICHTER, R., SCHMIDT, H., SDZUY, K., StruVE, W., TrIPP, R., Weller, J.M. \& WhitTington, H.B. 1959. Systematic descriptions, O170-O560. In MoORE, R.C. (ed.) Treatise on Invertebrate Paleontology, Part O, Arthropoda 1. Geological Society of America \& University of Kansas Press, New York \& Lawrence, Kansas.

Hou, X., Aldridge, R.J., BERGSTRÖM, J., Siveter, D.J., SIVETER, D.J. \& FENG, X.H. 2004. The Cambrian Fossils of Chengjiang, China. The Flowering of Early Animal Life. 233 pp. Blackwell Science Ltd., Malden, Massachusetts.

HOU, X. \& BERGSTRÖM, J. 1997. Arthropods of the Lower Cambrian Chengjiang fauna, southwest China. Fossils \& Strata 45, 1-116.
HoU, X. \& BerGSTRÖM, J. 2006. Dinocaridids: anomalous arthropods or arthropod-like worms?, 139-158. In RONG, J., FANG, Z., ZHOU, Z., ZHAN, R., WANG, X. \& YUAN, X. (eds) Originations, Radiations and Biodiversity Changes - evidences from the Chinese fossil record. Science Press, Beijing.

HoU, X., CHEN, J. \& LU, H. 1989. Early Cambrian new arthropods from Chengjiang, Yunnan. Acta Palaeontologica Sinica 28, 42-57. [in Chinese]

Hou, X., RAMSKÖLD, L. \& BERGSTRÖM, J. 1991. Composition and preservation of the Chengjiang fauna - a Lower Cambrian soft-bodied biota. Zoologica Scripta 20, 395-411. DOI 10.1111/j.1463-6409.1991.tb00303.x

INESON, J.R. \& PEEL, J.S. 1997. Cambrian shelf stratigraphy of North Greenland. Geology of Greenland Survey Bulletin 173, 1-120.

IVAntsov, A.Y., ZHURAVleV, A.Y., LegutA, A.V., KRASSILOV, V.A., Melnikova, L.M. \& UshatinskayA, G.T. 2005. Palaeoecology of the Early Cambrian Sinsk biota from the Siberian Platform. Palaeogeography, Palaeoclimatology, Palaeoecology 220, 69-88. DOI 10.1016/j.palaeo.2004.01.022

LAGEBro, L., STEIN, M. \& PEEL, J.S. 2009. A new ?lamellipedian arthropod from the early Cambrian Sirius Passet Fauna of North Greenland. Journal of Paleontology 83, 820-825.

DOI 10.1666/09-011.1

LUO, H., HU, S., ZHANG, S. \& TAO, Y. 1997. New occurrence of the Early Cambrian Chengjiang Fauna in Haikou, Kunming, Yunnan Province, and study on Trilobitoidea. Acta Geologica Sinica 71, $122-132$.

PEEL, J.S. \& SøNDERHOLM, M. (eds) 1991. Sedimentary basins of North Greenland. Grønlands Geologiske Undersøgelse Bulletin $160,1-164$.

RIGBY, J.K. 1986. Cambrian and Silurian sponges from North Greenland. Grønlands Geologiske Undersøgelse Rapport 126, 51-63.

SiEBOLD, C.T.E. \& STANNIUS, H. 1845. Lehrbuch der Vergleichenden Anatomie. Von Veit, Berlin.

SimonetTA, A.M. \& Delle CAVE, L. 1991. Early Palaeozoic arthropods and problems of arthropod phylogeny; with some notes on taxa of doubtful affinities, 189-244. In SIMONETTA, A.M. \& CONWAY MORRIS, S. (eds) The early evolution of Metazoa and the significance of problematic taxa. Cambridge University Press, Cambridge.

STEIN, M. In press. A new arthropod from the Early Cambrian of North Greenland with a 'great appendage' like antennule. Zoological Journal of the Linnean Society.

DOI 10.1111/j.1096-3642.2009.00562.x

Stein, M., PeEl, J.S., Siveter, D.J. \& Williams, M. In press. Isoxys (Arthropoda) with preserved soft anatomy from the Sirius Passet Lagerstätte, lower Cambrian of North Greenland. Lethaia. DOI 10.1111/j.1052-3931.2009.00189.x

STØRMER, L. 1959. Trilobitoidea, O23-O37. In MOORE, R.C. (ed.) Treatise on Invertebrate Paleontology Part O, Arthropoda 1. Geological Society of America \& University of Kansas Press, New York \& Lawrence, Kansas.

TAYLOR, R.S. 2002. A new bivalved arthropod from the Early Cambrian Sirius Passet fauna, North Greenland. Palaeontology 45, 97-123. DOI 10.1111/1475-4983.00229

VINTHER, J. \& NIELSEN, C. 2005. The Early Cambrian Halkieria is a mollusc. Zoologica scripta 34, 81-89. DOI 10.1111/j.1463-6409.2005.00177.x

Williams, M., SiVETER, D.J. \& PEEL, J.S. 1996. Isoxys (Arthropoda) from the Early Cambrian Sirius Passet Lagerstätte, North Greenland. Journal of Paleontology 70, 947-954.

ZHU, M., BABCOCK, L.E. \& PENG, S. 2006. Advances in Cambrian stratigraphy and paleontology: integrating correlation techniques, paleobiology, taphonomy and paleoenvironmental reconstruction. Palaeoworld 15, 217-222. DOI 10.1016/j.palwor.2006.10.016 